\title{
Platelets, coagulation and fibrinolysis in breast cancer progression
}

\author{
Inder Lal, Kim Dittus and Chris E Holmes*
}

\begin{abstract}
The progression of breast cancer from early-stage to metastatic disease results from a series of events during which malignant cells invade and travel within the bloodstream to distant sites, leading to a clonogenic accumulation of tumor cells in non-breast tissue. While mechanistically complex, an emerging literature supports hemostatic elements as an important patient factor that facilitates the metastatic potential of breast cancer. Hemostatic elements involved include platelets, coagulation, and fibrinolysis. Key steps in breast tumor progression, including cellular transformation, proliferation, tumor cell survival, and angiogenesis, can be mediated by components of the hemostatic system. Thus, the hemostatic system provides potential targets for novel therapeutic approaches to breast cancer therapy with drugs in current use and in development. The present article provides a comprehensive overview of the evidence and mechanisms supporting the roles played by platelets, coagulation activation, and the fibrinolytic system in breast cancer progression.
\end{abstract}

\section{Introduction}

Like the host tumor microenvironment and immune response, the host hemostatic system represents one of several patient factors now recognized as important in both the control and progression of malignancy. In women with breast cancer, the relationship between the tumor and the hemostatic system is increasingly recognized as an important regulator of breast cancer progression. In fact, elements of the hemostatic system, including platelets, coagulation, and fibrinolysis, can affect many of the processes known to mediate breast cancer progression. For example, clearly defined cancer hallmarks such as sustained proliferation, evasion from

*Correspondence: ceholmes@med.uvm.edu

Division of Hematology and Oncology, Department of Medicine, University of Vermont, 89 Beaumont Avenue, Burlington, VT 05405-0110, USA immune-mediated destruction, apoptosis prevention, angiogenesis, tumor invasion, and metastasis [1] are directly impacted by elements of the hemostatic system.

We review the available evidence that suggests a reciprocal interplay between breast cancer and the hemostatic system and delineate the important role played by platelets, coagulation, and fibrinolysis components in each step of tumor growth and metastasis in patients with breast cancer (Figure 1). In addition, we will highlight potential hemostasis-targeting strategies that may be of therapeutic benefit in patients with either early or later stages of the disease. Importantly, many laboratories have contributed significantly to our understanding of the potential role of the hemostatic system in the progression of a variety of cancers by using various tumor models. Although this evidence is undoubtedly important and robust, we have focused, in this review, only on laboratory, murine, and clinical models that involve breast cancer.

\section{Platelets and breast cancer}

An increased risk of thrombosis as well as increased platelet activation has been observed for decades in women with breast cancer, but until recently, these clinical observations have been considered a paraneoplastic phenomenon [2-6]. In women in whom breast cancer has been diagnosed, an increased circulating platelet count (thrombocytosis) is associated with a poor cancer prognosis, suggesting a potential direct role for platelets in the pathogenesis of the disease $[7,8]$. Analogous to the recent elucidation of the role of platelets in inflammation, wound healing, and sepsis, experimental and clinical evidence now suggests that platelets may play a role in breast cancer progression $[9,10]$.

The relationship between platelets and breast cancer metastasis has been recognized since 1968, when Gasic and colleagues [11] demonstrated, in an animal model, a $50 \%$ reduction in tumor metastasis after experimental thrombocytopenia induced with neuraminidase and antiplatelet serum. This anti-metastatic effect was effectively reversed with infusion of platelet-rich plasma (blood plasma enriched with platelets obtained by centrifugation and removal of red blood cells). Since that time, numerous studies have contributed to our understanding 


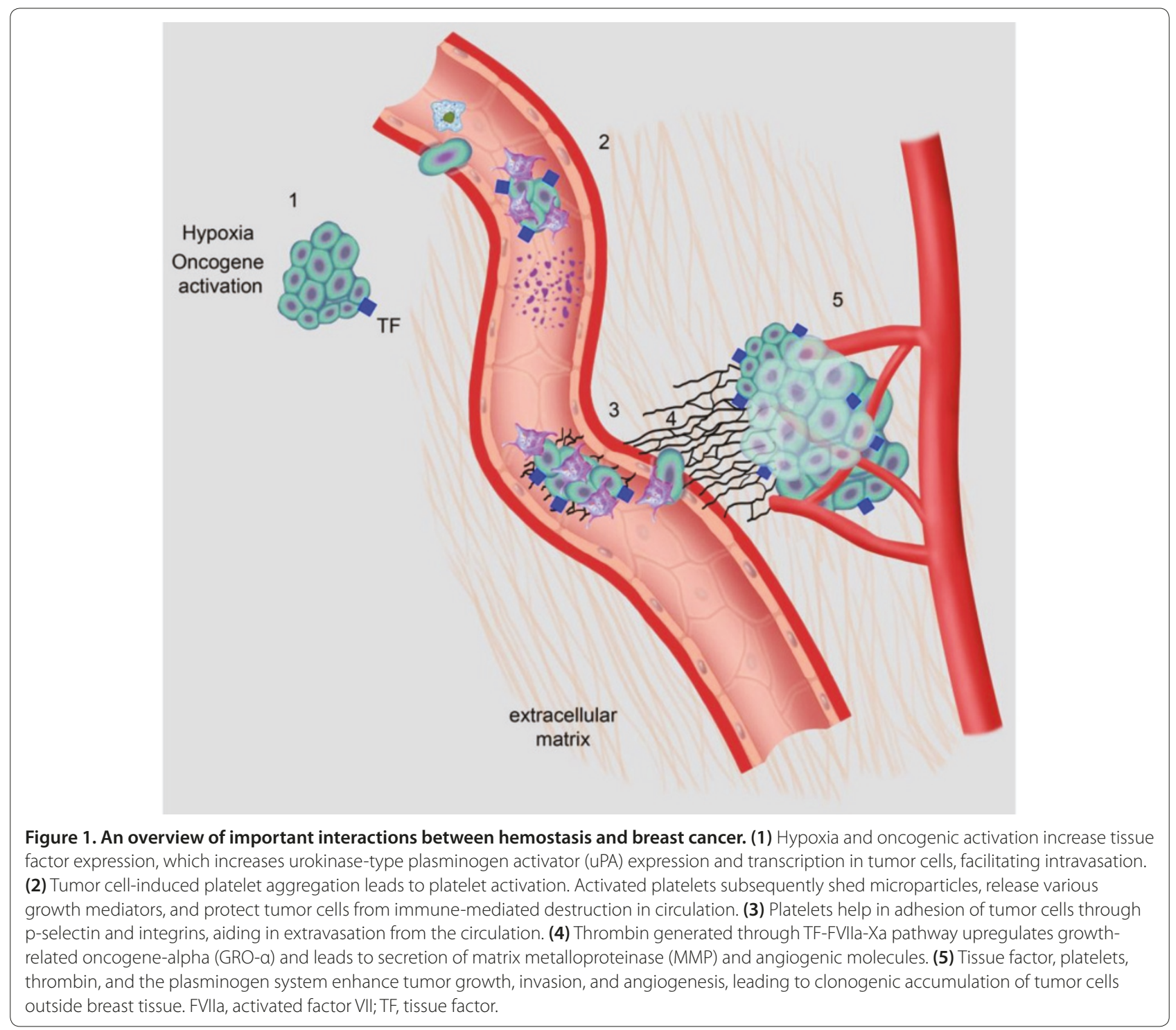

of the role of platelets in multiple steps in breast cancer progression. Platelet roles in breast cancer progression, including increased survival of disseminated cancer cells within the circulation, tumor cell adhesion to the endothelium, extravasation into the parenchyma of distant tissues, and ultimately the growth of tumor cells at metastatic sites, are reviewed below $[5,9,12-17]$.

\section{Platelet activation}

In response to stimuli, platelets undergo a process of activation that leads to shape change, small-molecule and protein release, and membrane-based changes. At least two markers of platelet activation - B-thromboglobulin and P-selectin - are increased in the blood of patients with breast cancer, suggesting that ongoing platelet activation occurs in these patients $[5,16]$. One mechanism of platelet activation is tumor cell-induced platelet aggregation (TCIPA). Importantly, the ability of breast tumor cells to induce platelet aggregation correlates with their metastatic potential $[6,18]$. TCIPA can occur via direct contact with tumor cells or by various mediators like ADP, thromboxane A2, or serine proteinases, including thrombi [19-21]. For example, in the laboratory, ADP released from MCF-7 breast cancer cells has been found to induce platelet aggregates via activation of the platelet $\mathrm{P}_{12} \mathrm{Y}_{12}$ receptor [6]. TCIPA has also been shown to enhance expression of glycoprotein (GP) Ib and IIb/IIIa receptors not only on platelets but also on breast cancer cells [6], and antibodies against GPIb and GPIIb/IIIa can inhibit platelet aggregation by breast cancer cells and attenuate metastasis [19,22]. Additional mechanisms of platelet activation include the generation of matrix metalloproteinases (MMPs) by breast cancer cells and general activation of the coagulation system (reviewed 
below and in [6]). Once activated, platelets as well as factors released from them promote metastasis by increasing survival of cancer cells within the circulation and facilitating adhesion to the endothelium, extravasation, and ultimately the growth of tumor cells at metastatic sites $[8,9,12-17,23,24]$. Additionally, platelets can shed microvesicles (platelet microvesicles) from their surface following activation and this can further enhance breast cancer cell adhesion, proliferation, chemotaxis, and chemoinvasion via several mechanisms [25].

\section{Platelets facilitate tumor cell survival in the circulation}

As cancer cells intravasate into the circulation, they are subject to a hostile environment resulting from immunological assault by natural killer (NK) cells and shear forces, which threaten their survival. Research using various in vivo and in vitro tumor models has shown that platelets can increase metastatic success via multiple mechanisms, including direct shielding of tumor cells, protection of tumor cells from tumor necrosis factoralpha (TNF- $\alpha$ )-mediated cytotoxicity, and facilitation of downregulation of NKG2D (immunoreceptor natural killer group 2, member D) via platelet-derived transforming growth factor-beta (TGF- $\beta$ ) $[9,26]$. Studies in breast cancer models have shown that direct interaction between breast cancer cells and platelets results in the activation of the TGF- $\beta$ signaling pathway, which promotes metastasis, and invasion by inducing epithelial-tomesenchymal transition and immunosuppression [14,27]. Placke and colleagues [12], using an ex vivo breast cancer model, found that platelets can transfer their MHC (major histocompatibility class 1 ) antigens to tumor cells and provide a pseudonormal phenotype to embolic tumor cells to help evade NK cell-mediated destruction. A recent study using a murine model also found that platelets promote breast cancer metastases in a timedependent manner; however, NK cell destruction of circulating tumor cells was not affected by platelets [28].

Platelets facilitate tumor cell adhesion to the endothelium In the circulation, an interaction between breast tumor cells and platelets, leukocytes, and endothelial cells occurs through numerous cellular proteins and receptors (reviewed in [9]). Generally, this interaction facilitates metastasis by promoting arrest of tumor cells in the circulation and extravasation at distant sites $[19,29]$. Two platelet receptors are particularly important in this process: p-selectin and GPIIb/IIIa (also known as $\alpha \operatorname{IIb} \beta 3$ ); these receptors are discussed further below. In addition to these two important platelet receptors, exposed collagen IV on tumor blood vessels has been shown to facilitate platelet recruitment in the tumor microenvironment and has been considered a marker for angiogenesis in breast cancer $[17,30]$.
The selectins are a family of adhesion molecules that mediate loose tethering engagement between tumor cells, platelets, leukocytes, and endothelial cells [31]. Pselectin is a cell adhesion molecule stored in the WeibelPalade bodies of endothelial cells and the alpha granules of platelets. P-selectin expression occurs on the platelet surface following their activation. Chondroitin sulfate glycosaminoglycan (CS-GAG) and CD24 are the major P-selectin-reactive ligands on the surface of breast cancer cells and their enhanced expression correlates with cancer progression and poor prognosis [17,29,32]. Selectin deficiency and removal of CS-GAG have been recently shown to reduce spontaneous metastasis in experimental and mouse models of breast cancer and provide an attractive treatment target $[28,29,32]$. Stubke and colleagues [29] have further found that selectin deficiency reduces but does not completely abrogate metastasis in a xenographic model of human breast cancer cells, suggesting a role for additional adhesion molecules. Coupland and colleagues [28] showed that, in a mouse model of metastatic breast carcinoma and melanoma, platelet-derived p-selectin promotes lung metastasis and platelet depletion reduced lung metastasis in both the presence and absence of NK cells. These observations suggest that P-selectin and $\mathrm{p}$-selectin ligands may be important targets in breast cancer therapy.

Selectin-mediated loose tethering is followed by firm adhesion of tumor cells to endothelium through upregulation of integrins [31]. Integrins are a family of transmembrane adhesion receptors composed of non-covalently linked $\alpha$ and $\beta$ subunits. TCIPA increases surface expression of platelet integrin GPIIb/IIIa $(\alpha \mathrm{IIb} \beta 3)$ [6]. Another integrin, $\alpha v \beta 3$, is highly expressed in patients with metastatic breast cancer and correlates with cancer progression and metastatic phenotype in breast cancer [33]. Interactions between platelet integrin $\alpha \operatorname{IIb} \beta 3$ and tumor cell integrin $\alpha v \beta 3$ in the presence of connecting plasma proteins such as fibrinogen leads to arrest of tumor cells in circulation [22]. Anti- $\alpha \operatorname{Ilb} \beta 3$ and anti- $\alpha v \beta 3$ can abolish arrest of breast cancer cells and help control metastasis [22].

\section{Platelets support the invasive phenotype and extravasation}

Matrix degradation by proteases is crucial for the processes of tumor cell invasion into the surrounding stroma and extravasation into blood vessels. Early work by Belloc and colleagues [34] in 1995 showed an increase in the invasiveness of human mammary tumor cells after exposure to platelets. Subsequently, activated platelets have been found to promote extravasation and an invasive phenotype in breast cancer through the release of MMPs from their alpha granules, the generation of MMPs from tumor cells, and the secretion of a plethora of important growth factors and enzymes like TGF- $\beta$, 
vascular endothelial growth factor (VEGF), plateletderived growth factor (PDGF), and lysophosphatidic acid (LPA) that affect vascular integrity $[6,14-16,18,34]$.

Direct signaling between platelets and breast cancer cells has been found to induce tumor cells to undergo an epithelial-to-mesenchymal-like transition, a transient and reversible process that promotes metastases by enhancing tumor cell motility, invasion, and dissemination of cancer cells out of the tumor microenvironment, in a breast tumor cell model [14]. In this model, plateletderived TGF $\beta$ and direct platelet-tumor cell contacts synergistically activated the TGF- $\beta$ and NF-kB (nuclear factor kappa-light-chain-enhancer of activated B cells) pathways in cancer cells leading to tumor epithelialmesenchymal transition (EMT). EMT leads to downregulation of E-cadherin and increased production of plasminogen activator inhibitor-1 (PAI-1), fibronectin, MMP-9, and multiple other factors that promote migration and invasion by breast cancer cells [14].

\section{Platelets support tumor growth and angiogenesis}

Tumor growth is dependent on the development of new blood vessels (angiogenesis). In patients with breast cancer, tumor cells may remain dormant at secondary sites for long periods in the absence of angiogenesis [17]. During cancer growth, the exquisite balance between pro- and anti-angiogenic factors is disrupted and results in a pro-angiogenic microenvironment contributing to progression and invasiveness $[16,17,23]$.

Platelets store more than 30 angiogenesis-regulating factors. These factors can be pro-angiogenic such as VEGF, fibroblast growth factor (FGF), PDGF, epidermal growth factor (EGF), hepatocyte growth factor (HGF), insulin-like growth factor (IGF), CD40 ligand, matrix metalloproteinases (MMP-1, MMP-2, and MMP-9), gelatinase A, and heparanase or can be anti-angiogenic such as angiostatin, thrombospondin-1, platelet factor-4, endostatin, TGF- $\beta$, and tissue inhibitor of matrix metalloproteinases (TIMP) $[16,23,24,35,36]$. VEGF is the most extensively studied pro-angiogenic protein, and the platelet pool comprises more than $80 \%$ of total circulating VEGF in healthy subjects as well as patients with cancer, including those with breast cancer [36,37]. In ex vivo models of platelet activation, angiogenic proteins are selectively released on the basis of differential platelet receptor activation by various agonists, suggesting that platelets may actively stimulate or inhibit angiogenesis [23,35,38]. Breast cancer cells have also been shown to prime platelets to release pro-angiogenic proteins which stimulate migration and proliferation of endothelial cells [23].

Platelets have also been shown to maintain vascular integrity in murine models of breast cancer and prevent intratumor hemorrhage and subsequent cell death [39]. Recently, Demers and colleagues [40] showed that in a mammary carcinoma murine model, thrombocytopenia (low platelet count) resulted in increased tumor leakiness and facilitated the delivery of chemotherapeutic agents to tumors, thereby increasing drug efficacy. These data suggest that platelet function and number likely play a role in modulating the tumor vasculature.

\section{Anti-platelet therapy in breast cancer}

Table 1 summarizes the current findings with regard to the role of platelets in breast cancer progression within the context of hallmarks that generally define cancer pathogenesis. The preponderance of the data to date suggests that anti-platelet therapy might be best used to prevent or attenuate metastatic spread. However, there is a paucity of clinical studies addressing the clinical utility of anti-platelet strategies in breast cancer control, and most inferences about platelet-inhibitory drugs (for example, aspirin) in cancer prevention have been extrapolated from meta-analysis of data from cardiovascular trials. Table 2 provides a summary of the clinical data from cancer-specific trials. A potentially important study is the Nurses' Health Study, which reported an association between aspirin use and a decrease in distant recurrence and improved survival in women with breast cancer who had survived a minimum of one year following a cancer diagnosis [41]. These data complement numerous studies in the literature that suggest a potential benefit for aspirin use in the primary prevention of breast cancer [42]. However, the clinical benefit of aspirin in patients with cancer has been linked to inhibition of cyclooxygenase in tumor cells, and inhibition of platelet activation has not been widely cited as a potential mechanism of action in these studies.

Currently available oral anti-platelet agents in addition to aspirin include ADP receptor antagonists (such as clopidogrel and prasugrel) and dipyridamole, a pyrimidopyrimidine derivative that blocks platelet uptake of adenosine and inhibits cyclic AMP phosphodiesterase [43]. These drugs inhibit platelet activation, are relatively well tolerated, and have a known safety profile. Use of these drugs may be of particular appeal to improve the survival of women with metastatic disease [44]. Combining these drugs with hormonal therapy and targeted therapy that does not produce thrombocytopenia would also be compelling in the clinical trial setting. A single murine study has suggested that aspirin use may be of benefit in a subset of patients with luminal breast cancer [17]; however, clinical studies are needed and are an important avenue of future research. Exploration of platelet receptor-specific inhibition and the effects on tumor progression in the metastatic and adjuvant settings is also exciting potential future research opportunities given the new drugs under development in the cardiovascular setting (for example, PAR-1 platelet inhibitors). 
Table 1. Hallmarks of cancer progression and roles played by the hemostatic system

\begin{tabular}{llll}
\hline Hallmarks of cancer progression & Platelets & Coagulation & Fibrinolysis \\
\hline Genetic instability & Indirect evidence only [86] & No & No \\
Tumor-promoting inflammation & No & Yes [51] & No \\
Sustained proliferative signaling & Yes $[14,15,25]$ & Yes [51] & Yes [76,78] \\
Evasion of anti-growth signaling & Yes [14] & No & No \\
Prevention of apoptosis & Yes [14] & Yes [51,86] & Yes [76-78] \\
Replicative immortality & No & No & No \\
Deregulated metabolism & No & No & No \\
Immune system evasion & Yes $[12]$ & No & No \\
Angiogenesis & Yes $[15,17,23,24]$ & Yes $[51,68,70,72]$ & Yes [79] \\
Tissue invasion and metastasis & Yes $[6,14,15,18,25,32]$ & Yes $[51,70]$ & Yes [76,77] \\
\hline
\end{tabular}

\section{Coagulation and breast cancer}

Enhanced activation of the coagulation system has been demonstrated in women with breast cancer and has long been associated with an increase in systemic venous thromboembolism (VTE) rates and decreased survival in these patients $[2,3]$. Treatments for breast cancer, including surgery, hormonal therapy, and chemotherapy, contribute to and enhance this hypercoagulable state (reviewed in [3]). A significant body of evidence has established that coagulation activation is not just an epiphenomenon in breast cancer progression but is also an important regulator of malignant transformation, tumor angiogenesis, and metastasis. The major components of the coagulation system that play a role in breast cancer progression include tissue factor (TF) and thrombin.

\section{Tissue factor and breast cancer}

TF is a $47-\mathrm{kDa}$ transmembrane glycoprotein that serves as the primary cellular initiator of the extrinsic coagulation pathway by acting as a ligand for factor VII/VIIa and ultimately activating factor X (reviewed in [45]). Research has shown that the TF/fVIIa/fXa complex, beyond its traditional role of maintaining vascular hemostasis, also plays an important role in breast cancer progression $[46,47]$. TF-mediated coagulation not only leads to thrombin generation and contributes to the procoagulant phenotype seen in patients with breast cancer but also activates intracellular signaling events by binding to protease-activated receptors 1 and 2 (PAR- 1 and PAR-2) that contribute to several tumor-related processes, including cell growth, motility, invasion, angiogenesis, and anti-apoptotic effects [46]. In contrast to full-length tissue factor (flTF), invasive breast cell lines have also been shown to produce a shorter and more soluble isoform, termed asTF (alternatively spliced TF) [48]. asTF increases the migration and invasion in breast cancer cell lines and, in other tumor models, has been shown to induce tumor angiogenesis as well by binding to integrins independent of fVIIa [48].
Clinically, TF is frequently overexpressed by the tumor cells of patients with breast cancer and correlates with a poor prognosis and decreased survival $[47,49]$. In human breast cancer, PAR-2 and TF upregulation have been shown to be associated with a marked phosphorylation of the TF cytoplasmic domain (pTF). Ryden and colleagues [49] found that, in patients with primary breast cancer, co-expression of PAR-2 and VEGF-A was associated with a more aggressive tumor phenotype as indicated by a correlation to higher histological grade (PAR-2 and VEGF-A) and estrogen receptor negativity (VEGF-A). Additionally, pTF and PAR-2 correlated with a shorter recurrence-free survival in patients with breast cancer, supporting the important role of TF in breast cancer progression [49]. During tumorigenesis, not only is TF expression upregulated on tumor cells but also increased expression is observed on tumor vasculature endothelial cells and monocytes $[47,50,51]$. Furthermore, tumor cells also shed TF-bearing microparticles that contribute to tumor progression and hypercoagulability $[46,47,52,53]$. Suppressing TF activity with anti-TF antibodies or all trans-retinoic acid can induce apoptosis and inhibit metastatic spread of human breast cancer cells [54-57]. Additionally, TF/VIIa complex can be used for selectively delivering target drug to TF-overexpressing cancer cells to enhance therapeutic efficacy and reduce toxic side effects [58]. These findings suggest that TF can play a critical role in breast cancer biology and progression.

TF expression in the breast cancer microenvironment is a complex process and appears to be regulated in part by oncogenes, hypoxia, and TGF- $\beta$. Oncogenic activation of human epidermal growth factor receptor-2 (HER-2) and epidermal growth factor receptor (EGFR) enhances TF expression on breast cancer cells, and trastuzumab and cetuximab (monoclonal antibodies to HER-2 and EGFR, respectively) as well as the EGFR inhibitor, erlotinib, can inhibit such a process, leading to less invasive phenotypes and decreased migration of breast cancer cells in vitro $[48,59]$. On the other hand, microRNA-19 
Table 2. Clinical trials using anti-platelet and anti-coagulation therapy

\begin{tabular}{|c|c|c|c|c|c|c|}
\hline Drug & Target & $\begin{array}{l}\text { Study } \\
\text { description }\end{array}$ & $\begin{array}{l}\text { Percentage of } \\
\text { patients with } \\
\text { breast cancer }\end{array}$ & Results & $\begin{array}{l}\text { Breast cancer- } \\
\text { specific results }\end{array}$ & Reference \\
\hline Aspirin & Platelets & $\begin{array}{l}\text { Prospective observational } \\
\text { study }\end{array}$ & $100 \%$ & $\begin{array}{l}\text { Decreased distant } \\
\text { recurrence and mortality }\end{array}$ & $\begin{array}{l}43 \% \text { risk reduction in } \\
\text { distant recurrence and } \\
74 \% \text { risk reduction in } \\
\text { mortality }\end{array}$ & [41] \\
\hline Benoral & Platelets & Double-blind & $100 \%$ & No survival benefit & & [87] \\
\hline \multirow[t]{2}{*}{ Dalteparin } & Coagulation & $\begin{array}{l}\text { Randomized clinical trial in } \\
\text { advanced-stage III and IV } \\
\text { solid tumors }\end{array}$ & $17 \%$ & $\begin{array}{l}\text { No survival benefit with } \\
\text { advanced malignancy } \\
\text { Improved survival in } \\
\text { subgroup of patients } \\
\text { with better prognosis }\end{array}$ & Unknown & {$[80]$} \\
\hline & & $\begin{array}{l}\text { Randomized double-blind } \\
\text { controlled study changed to } \\
\text { open-labeled clinical trial }\end{array}$ & $10.8 \%$ & $\begin{array}{l}\text { No survival benefit with } \\
\text { advanced cancer }\end{array}$ & Unknown & [81] \\
\hline \multirow[t]{2}{*}{ Nadroparin } & Coagulation & $\begin{array}{l}\text { Randomized clinical trial } \\
\text { in locally advanced or } \\
\text { metastasized solid tumors } \\
\text { without any concomitant } \\
\text { chemotherapy or radiation } \\
\text { treatment }\end{array}$ & $16.5 \%$ & $\begin{array}{l}\text { Improved survival } \\
\text { (especially more } \\
\text { pronounced in patients } \\
\text { with estimated life } \\
\text { expectancy of } 6 \text { months } \\
\text { or greater) }\end{array}$ & Hazard ratio of 0.78 & [82] \\
\hline & & Randomized clinical trial & $14 \%$ & No survival benefit & Unknown & [83] \\
\hline Warfarin & Coagulation & $\begin{array}{l}\text { Double-blind randomized } \\
\text { trial }\end{array}$ & $100 \%$ & $\begin{array}{l}\text { No detectable survival } \\
\text { benefit but decreased } \\
\text { relative risk of venous } \\
\text { thromboembolism by } \\
85 \%\end{array}$ & & [84] \\
\hline
\end{tabular}

(miR-19) can downregulate TF expression in breast cancer cell lines and is highly expressed in MCF-7 cells (a weakly invasive breast cancer cell line) compared with MDA-MB-231 cells (a highly invasive cell breast cancer cell line) [60]. Hypoxia not only increases the expression of TF but also enhances ectopic synthesis of its ligand FVIIa in breast cancer cells via hypoxia-inducible factor- $2 \alpha$ (HIF$2 \alpha)$ [61]. Furthermore, breast cancer cells induce the expression of TF on vascular endothelial cells and stromal cells associated with cancer cells via production of VEGF and TGF- $\beta$ (an essential cytokine for EMT), respectively $[50,62]$. Additional mutant oncogenes (such as MET and PML-RAR-alpha) or loss of tumor suppressor genes (like PTEN and p53) have been shown to alter expression of TF and other mediators of cancer coagulopathy (PAI-1 and cyclooxygenase) in an oncotype-specific manner [63].

Enhanced cell migration and resistance to apoptosis are two important steps in metastasis and tumor growth. TF and TF complexes have been found to contribute to both of these processes (Figure 2). In vitro studies have demonstrated that the TF-VIIa-Xa complex promotes breast cancer cell migration through PAR-2 signaling and subsequent activation of mTOR (mammalian target of ripamycin) and MAPK (mitogen-activated protein kinase) pathways in the cancer cell $[51,64,65]$. TF/VIIa also enhances migration via induced transcription of interleukin 8 (IL-8) and colony-stimulating factor 1 (CSF-1) $[51,65]$.

\section{Thrombin and breast cancer progression}

The serine protease, thrombin, is generated via proteolytic cleavage from inactive prothrombin by factor $\mathrm{Xa}$ (fXa) in the prothrombinase complex and leads to blood clot formation to provide hemostasis during vascular damage. Thrombin converts fibrinogen to fibrin to stabilize blood clots and activates platelets which augment additional thrombin formation. Thrombin signaling activates G-protein-coupled PARs on cell surfaces to mediate some of its effects [66]. The generation of thrombin is central to blood clot formation in both healthy patients and those with cancer.

Some metastatic models of breast cancer have suggested that, in addition to TF, thrombin plays a pivotal role in the malignant potential and metastasis of breast cancer cells. In these studies, thrombin increased the invasiveness of breast cancer, and thrombin receptor (PAR-1) overexpression has been reported in invasive phenotypes in breast biopsy specimens from patients as 


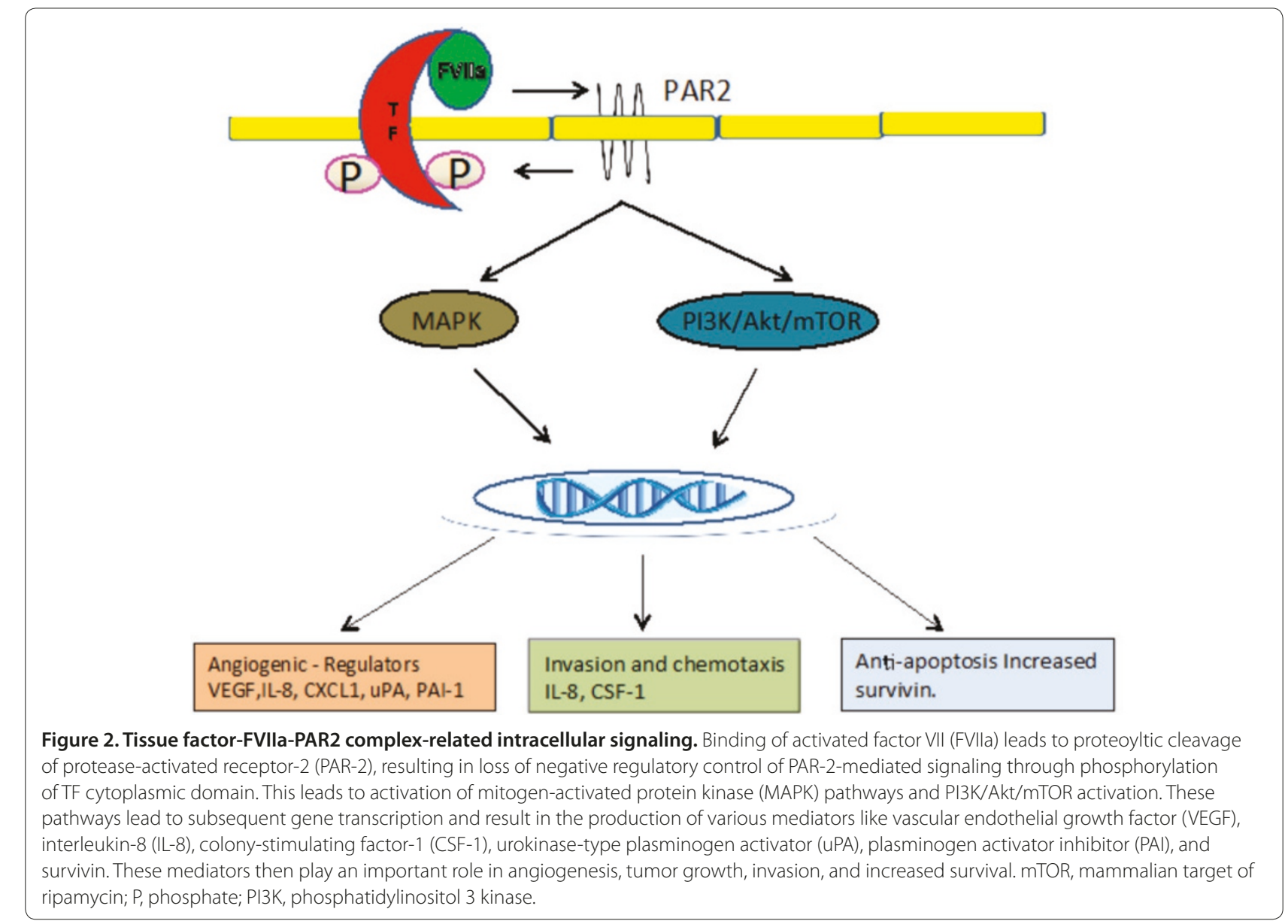

well as in xenographic models $[67,68]$. Hirudin, a potent and specific inhibitor of thrombin, has been shown to decrease tumor implantation, seeding, and spontaneous metastasis, supporting the notion that tumor cellinduced endogenous thrombin plays a significant role in the progression of breast cancer [68]. Additionally, in at least one laboratory model, a direct thrombin inhibitor (dabigatran) has been shown to inhibit both invasion and metastasis of malignant breast cancer cells [69].

In another combined in vitro and xenographic model, thrombin markedly upregulated chemokine growthregulated oncogene-alpha (GRO- $\alpha)$ in breast cancer cells as well as endothelial cells. Thrombin and GRO- $\alpha$ lead to increased production of various vascular regulatory and growth proteins important in angiogenesis and tumor progression, such as MMP-1, MMP-2, VEGF, angiopoietin-2 (Ang-2), CD31, and VEGF receptors KDR and the GRO- $\alpha$ receptor, CXCR2 (Figure 3). Anti-GRO- $\alpha$ antibodies effectively decrease thrombin-induced angiogenesis in endothelial cells, and injection of GRO- $\alpha \mathrm{KD}$ (GRO $\alpha$ knockdown)-4T1 murine mammary cells in mice results in decreased tumor growth, angiogenesis, and metastasis, supporting the important role of thrombin in breast cancer progression [70].

\section{Coagulation promotes tumor growth and angiogenesis}

In certain models, TF signaling was demonstrated to be crucial for breast cancer growth [71]. These findings are perhaps explained by the fact that TF can enhance angiogenesis indirectly through thrombin generation, fibrin deposition, and platelet activation [68,72]. Moreover, it is well established that thrombin stimulates platelets to release pro-angiogenic proteins, like VEGF, from platelet alpha-granules [46]. Under normal circumstances, fibrin, generated from the coagulation cascade, provides a proangiogenic matrix that promotes new blood vessel growth [73]. In vitro studies demonstrate that, in addition to a clotting-dependent pathway, direct TF/FVIIa-mediated PAR-2 activation induces production of angiogenic regulators, such as IL-8, CXCL1, VEGF, uPA, and PAI-1, as well as immunomodulators like colony-stimulating factors (granulocyte macrophage-colony-stimulating factor and macrophage-colony-stimulating factor) from breast cancer cells [51]. Several of these secreted proteins play 


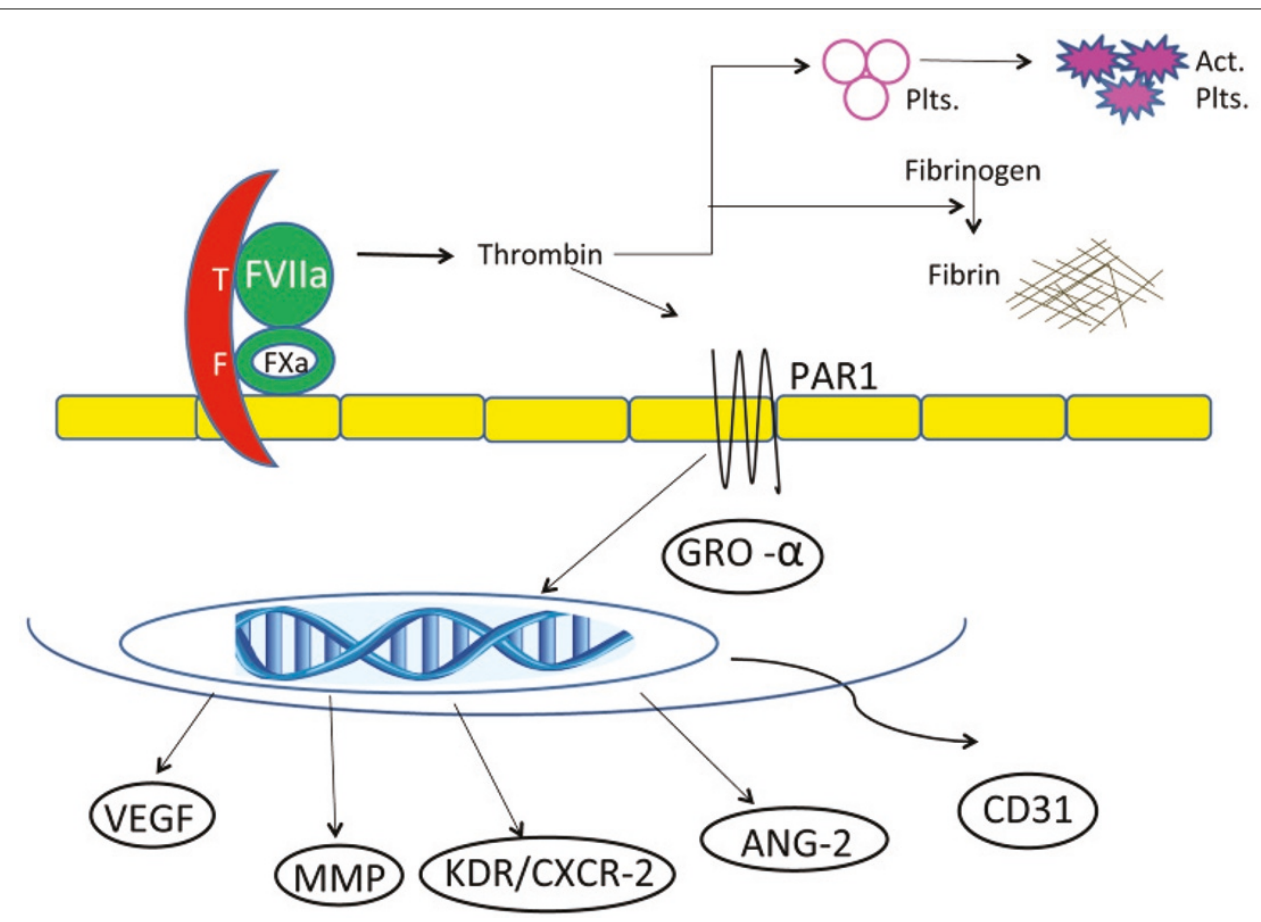

Figure 3. TF-FVIla-Xa complex results in thrombin generation. Thrombin is a potent platelet activator and also converts fibrinogen to fibrin, contributing to tumor metastasis. In breast cancer, thrombin acts through protease-activated receptor-1 (PAR-1) receptor and markedly increases growth-related oncogene-alpha (GRO-a) production. Thrombin, PAR activation peptide, and GRO-a all lead to increased production of matrix metalloproteinase (MMP), vascular endothelial growth factor (VEGF), angiopoietin-2 (ANG-2), CD31, and receptors KDR/CXCR-2 in endothelial cells, contributing to tumor growth, angiogenesis, and metastasis. Act. Plts., activated platelets; CXCR2, chemokine receptor for growth-related oncogene-alpha; KDR, kinase insert domain receptor (vascular endothelial growth factor receptor); Plts., platelets.

important roles in angiogenesis, apoptosis/survival, cell proliferation, cell migration, and cell adhesion.

\section{The fibrinolytic system and breast cancer}

By virtue of its role in normal physiological processes, the fibrinolytic system has also attracted attention as a possible mediator of breast cancer progression. The fibrinolytic system is central to controlling thrombus dissolution (for example, upon wound healing). Hence, in recent years, researchers have begun to unravel the pathophysiologic role of the fibrinolytic system in breast cancer progression. System components that have been demonstrated to play important roles in breast cancer include urokinase-type plasminogen activator (uPA), its receptor UPAR, and PAI-1 [74]. The fibrinolytic system promotes tumor growth by several different mechanisms, including angiogenesis, suppressing apoptosis, proliferation of tumor cells, and degradation of extracellular matrix [74]. Clinically, increased levels of both uPA and PAI-1 correlate with poor relapse-free survival and poor overall survival in patients with breast cancer [75]. Particularly in patients with untreated, lymph node-negative breast cancer, combined uPA and
PAI-1 levels demonstrated a strong prognostic ability, and elevated levels of UPA and PAI- 1 in these patients might be used as a marker for high-risk disease and to determine the need for chemotherapy [75].

One mechanism by which UPA, PAI-1, and UPAR mRNA expression can be increased in human breast cancer is via activation through the TF-FVIIa-PAR-2 complex [51]. uPA converts plasminogen to plasmin, which degrades the extracellular matrix to assist in invasion and metastasis [76]. Malinowsky and colleagues $[76,77]$ have also demonstrated a positive correlation between uPA/PAI-1 with PI3K/Akt and MAPK signaling pathway molecules in tissue biopsies obtained from patients with breast cancer. These pathways are thought to promote tumor growth by suppressing apoptosis and inducing proliferation [76,77]. uPA also activates tumorderived PDGF-C in breast cancer cell lines and this enhances cell proliferation, cell growth, and tumor cell motility [78]. Apart from increased plasminogen activity seen in tumor cells, at least two human breast cancer cell lines - MCF-7 and MDA MB 231 - have also been shown to promote angiogenesis by enhancing uPA and PAI expression by endothelial cells in in vitro models [79]. 


\section{Inhibitors of coagulation and fibrinolysis in the treatment} of breast cancer

In women with breast cancer, inhibitors of coagulation such as low-molecular-weight heparin and warfarin have been studied in clinical trials [80-84] (Table 2). Clinical trials presented in Table 2 largely enrolled patients with other malignancies, and patients with breast cancer represented a minority in most trials. The single trial using warfarin therapy that enrolled only patients with breast cancer did not find a survival benefit with the drug at doses designed to attain an international normalized ratio of 1.3 to 1.9 (mean of 1.52) in patients with metastatic disease. It is unclear from the existing data which patients would benefit from anti-coagulants and at what stage of the disease these drugs would be most optimally used. The data in these studies and those available for other tumors suggest that patients with a lower burden of disease might benefit most from anti-coagulation therapy. The dose needed for any potential clinically significant anti-cancer effect is unknown for these drugs and may be less or more than that needed to prevent thrombosis. Establishing doses for these drugs that might inhibit cancer progression is particularly important in order to minimize the bleeding risk associated with their use. In this regard, translational clinical studies are urgently needed. In addition, the use of these drugs in patients with specific cancer subtypes should be explored [59]. New anti-coagulants recently approved by the US Food and Drug Administration in cardiovascular disease, such as rivoraxaban (an oral factor Xa inhibitor) and dabigatran (an oral direct thrombin inhibitor), have undergone no clinical study in patients with breast cancer. Similarly, we are aware of no trials that focus on inhibitors of fibrinolysis.

\section{Conclusions}

Our current understanding of the role of hemostasis in breast cancer progression is still modest. However, the mechanisms and pathways highlighting the tumor-promoting effects of platelets, coagulation, and fibrinolysis are being increasingly identified. Many laboratory and animal studies have identified specific targets for hemostatic-targeted therapy that may be advantageous as adjuncts to existing cancer treatments. It is important to point out that the available evidence that supports the role of the hemostatic system in cancer progression extends well beyond breast cancer models. Although we have chosen to highlight only data that directly tested experimental or animal models of breast cancer, much additional and robust data exist in other tumor models that further support the role of the hemostatic system in cancer progression.

Currently, clinical data are limited for breast cancer and all tumor types with regard to efficacy of targeting the hemostatic system. Given the well-delineated sideeffect profile of anti-platelet and anti-coagulant therapy, the need for well-designed clinical trials and translational studies is imperative. The fear of bleeding complications with all currently available agents that inhibit the hemostatic system is real. However, relative to the toxicity of agents currently used in the neo-adjuvant - and, particularly, metastatic - setting, these drugs may be well tolerated (at least on the basis of current dosing levels established for the drugs in other clinical settings). The cost of these agents is also substantially less, and availability is, in many cases, immediate.

\section{Abbreviations}

asTF, alternatively spliced tissue factor; CS-GAG, chondroitin sulfate glycosaminoglycan; CXCL 1, chemokine ligand 1; CXCR2, chemokine receptor 2; EGFR, epidermal growth factor receptor; EMT, epithelial-mesenchymal transition; FVIla, activated factor VII; GP, glycoprotein; GRO-a, growth-related oncogenealpha; IL-8, interleukin-8; MAPK, mitogen-activated protein kinase; MMP, matrix metalloproteinase; NK, natural killer; PAI, plasminogen activator inhibitor; PAR, protease-activated receptor; PDGF, platelet-derived growth factor; PI3K, phosphatidyl inositol 3 kinase; TCIPA, tumor cell-induced platelet aggregation; TF, tissue factor; TGF- $\beta$, transforming growth factor-beta; UPA, urokinase-type plasminogen activator; VEGF, vascular endothelial growth factor.

\section{Competing interests}

The authors declare that they have no competing interests.

\section{Acknowledgments}

This work was supported by a grant from the American Cancer Society (116284-MRSG-08-111-01-CCE) and the Vermont Cancer Center at the University of Vermont.

Published: 31 July 2013

\section{References}

1. Hanahan D, Weinberg RA: Hallmarks of cancer: the next generation. Cell 2011, 144:646-674.

2. Chew HK, Wun T, Harvey DJ, Zhou H, White RH: Incidence of venous thromboembolism and the impact on survival in breast cancer patients. J Clin Oncol 2007, 25:70-76.

3. Caine GJ, Stonelake PS, Rea D, Lip GY: Coagulopathic complications in breast cancer. Cancer 2003, 98:1578-1586.

4. Caine GJ, Lip GY, Stonelake PS, Ryan P, Blann AD: Platelet activation, coagulation and angiogenesis in breast and prostate carcinoma. Thromb Haemost 2004, 92:185-190.

5. Ferriere JP, Bernard D, Legros M, Chassagne J, Chollet P, Gaillard G, Plagne R: beta-Thromboglobulin in patients with breast cancer. Am J Hematol 1985, 19:47-53.

6. Alonso-Escolano D, Strongin AY, Chung AW, Deryugina El, Radomski MW Membrane type-1 matrix metalloproteinase stimulates tumour cellinduced platelet aggregation: role of receptor glycoproteins. $\mathrm{Br}$ J Pharmacol 2004, 141:241-252.

7. Taucher S, Salat A, Gnant M, Kwasny W, Mlineritsch B, Menzel RC, Schmid M, Smola MG, Stierer M, Tausch C, Galid A, Steger G, Jakesz R; Austrian Breast and Colorectal Cancer Study Group: Impact of pretreatment thrombocytosis on survival in primary breast cancer. Thromb Haemost 2003, 89:1098-1106.

8. Sierko E, Wojtukiewicz MZ: Platelets and angiogenesis in malignancy. Semin Thromb Hemost 2004, 30:95-108.

9. Bambace NM, Holmes CE: The platelet contribution to cancer progression. J Thromb Haemost 2011, 9:237-249.

10. Nurden AT: Platelets, inflammation and tissue regeneration. Thromb Haemost 2011, 105 Suppl 1:S13-33.

11. Gasic GJ, Gasic TB, Stewart CC: Antimetastatic effects associated with platelet reduction. Proc Natl Acad Sci U S A 1968, 61:46-52.

12. Placke T, Orgel M, Schaller M, Jung G, Rammensee HG, Kopp HG, Salih HR: Platelet-derived MHC class I confers a pseudonormal phenotype to cancer cells that subverts the antitumor reactivity of natural killer immune cells. 
Cancer Res 2012, 72:440-448.

13. Karpatkin S, Ambrogio C, Pearlstein E: The role of tumor-induced platelet aggregation, platelet adhesion and adhesive proteins in tumor metastasis. Prog Clin Biol Res 1988, 283:585-606.

14. Labelle M, Begum S, Hynes RO: Direct signaling between platelets and cancer cells induces an epithelial-mesenchymal-like transition and promotes metastasis. Cancer Cell 2011, 20:576-590.

15. Boucharaba A, Guillet B, Menaa F, Hneino M, van Wijnen AJ, Clezardin P, Peyruchaud O: Bioactive lipids lysophosphatidic acid and sphingosine 1-phosphate mediate breast cancer cell biological functions through distinct mechanisms. Oncol Res 2009, 18:173-184.

16. Caine GJ, Lip GY, Blann AD: Platelet-derived VEGF, Flt-1, angiopoietin-1 and P-selectin in breast and prostate cancer: further evidence for a role of platelets in tumour angiogenesis. Ann Med 2004, 36:273-277.

17. Kuznetsov HS, Marsh T, Markens BA, Castaño Z, Greene-Colozzi A, Hay SA, Brown VE, Richardson AL, Signoretti S, Battinelli EM, McAllister SS: Identification of luminal breast cancers that establish a tumor-supportive macroenvironment defined by proangiogenic platelets and bone marrow-derived cells. Cancer Discov 2012, 2:1150-1165.

18. Alonso-Escolano D, Medina C, Cieslik K, Radomski A, Jurasz P, Santos-Martinez MJ, Jiffar T, Ruvolo P, Radomski MW: Protein kinase C delta mediates platelet-induced breast cancer cell invasion. J Pharmacol Exp Ther 2006, 318:373-380.

19. Oleksowicz L, Mrowiec Z, Schwartz E, Khorshidi M, Dutcher JP, Puszkin E: Characterization of tumor-induced platelet aggregation: the role of immunorelated GPIb and GPIIb/IIla expression by MCF-7 breast cancer cells. Thromb Res 1995, 79:261-274.

20. Pacchiarini L, Zucchella M, Milanesi G, Tacconi F, Bonomi E, Canevari A, Grignani G: Thromboxane production by platelets during tumor cellinduced platelet activation. Invasion Metastasis 1991, 11:102-109.

21. Grignani G, Pacchiarini L, Ricetti MM, Dionigi P, Jemos V, Zucchella M, Fratino P: Mechanisms of platelet activation by cultured human cancer cells and cells freshly isolated from tumor tissues. Invasion Metastasis 1989, 9:298-309.

22. Felding-Habermann B, O'Toole TE, Smith JW, Fransvea E, Ruggeri ZM, Ginsberg MH, Hughes PE, Pampori N, Shattil SJ, Saven A, Mueller BM: Integrin activation controls metastasis in human breast cancer. Proc Natl Acad Sci USA 2001, 98:1853-1858.

23. Battinelli EM, Markens BA, Italiano JE Jr.: Release of angiogenesis regulatory proteins from platelet alpha granules: modulation of physiologic and pathologic angiogenesis. Blood 2011, 118:1359-1369.

24. Tokyol C, Ersoz G, Dilek FH, Gencer E, Kosar MN, Dilek ON: Thrombospondin 1 expression and angiogenesis in breast carcinoma and their relation with platelet activity. Ups J Med Sci 2009, 114:108-115.

25. Janowska-Wieczorek A, Marquez-Curtis LA, Wysoczynski M, Ratajczak MZ: Enhancing effect of platelet-derived microvesicles on the invasive potential of breast cancer cells. Transfusion 2006, 46:1199-1209.

26. Kopp HG, Placke T, Salih HR: Platelet-derived transforming growth factorbeta down-regulates NKG2D thereby inhibiting natural killer cell antitumor reactivity. Cancer Res 2009, 69:7775-7783.

27. Drabsch $Y$, ten Dijke P: TGF-beta signaling in breast cancer cell invasion and bone metastasis. J Mammary Gland Biol Neoplasia 2011, 16:97-108.

28. Coupland LA, Chong BH, Parish CR: Platelets and P-selectin control tumor cell metastasis in an organ-specific manner and independently of NK cells. Cancer Res 2012, 72:4662-4671.

29. Stubke K, Wicklein D, Herich L, Schumacher U, Nehmann N: Selectindeficiency reduces the number of spontaneous metastases in a xenograft model of human breast cancer. Cancer Lett 2012, 321:89-99.

30. Mazouni C, Arun B, Andre F, Ayers M, Krishnamurthy S, Wang B, Hortobagyi GN, Buzdar AU, Pusztai L: Collagen IV levels are elevated in the serum of patients with primary breast cancer compared to healthy volunteers. $\mathrm{Br}$. Cancer 2008, 99:68-71.

31. Brooks SA, Lomax-Browne HJ, Carter TM, Kinch CE, Hall DM: Molecular interactions in cancer cell metastasis. Acta Histochem 2010, 112:3-25.

32. Cooney CA, Jousheghany F, Yao-Borengasser A, Phanavanh B, Gomes T, Kieber-Emmons AM, Siegel ER, Suva L, Ferrone S, Kieber-Emmons T, Monzavi-Karbassi B: Chondroitin sulfates play a major role in breast cancer metastasis: a role for CSPG4 and CHST11 gene expression in forming surface P-selectin ligands in aggressive breast cancer cells. Breast Cancer Res 2011, 13:R58.

33. Liapis H, Flath A, Kitazawa S: Integrin alpha V beta 3 expression by boneresiding breast cancer metastases. Diagn Mol Pathol 1996, 5:127-135.
34. Belloc C, Lu H, Soria C, Fridman R, Legrand Y, Menashi S: The effect of platelets on invasiveness and protease production of human mammary tumor cells. Int J Cancer 1995, 60:413-417.

35. Bambace NM, Levis JE, Holmes CE: The effect of P2Y-mediated platelet activation on the release of VEGF and endostatin from platelets. Platelets 2010, 21:85-93.

36. Peterson JE, Zurakowski D, Italiano JE Jr., Michel LV, Fox L, Klement GL, Folkman J: Normal ranges of angiogenesis regulatory proteins in human platelets. Am J Hematol 2010, 85:487-493.

37. Holmes CE, Huang JC, Pace TR, Howard AB, Muss HB: Tamoxifen and aromatase inhibitors differentially affect vascular endothelial growth factor and endostatin levels in women with breast cancer. Clin Cancer Res 2008, 14:3070-3076.

38. Italiano JE Jr., Richardson JL, Patel-Hett S, Battinelli E, Zaslavsky A, Short S, Ryeom S, Folkman J, Klement GL: Angiogenesis is regulated by a novel mechanism: pro- and antiangiogenic proteins are organized into separate platelet alpha granules and differentially released. Blood 2008, 111:1227-1233.

39. Ho-Tin-Noe B, Carbo C, Demers M, Cifuni SM, Goerge T, Wagner DD: Innate immune cells induce hemorrhage in tumors during thrombocytopenia. Am J Pathol 2009, 175:1699-1708.

40. Demers M, Ho-Tin-Noe B, Schatzberg D, Yang JJ, Wagner DD: Increased efficacy of breast cancer chemotherapy in thrombocytopenic mice. Cancer Res 2011, 71:1540-1549.

41. Holmes MD, Chen WY, Li L, Hertzmark E, Spiegelman D, Hankinson SE: Aspirin intake and survival after breast cancer. J Clin Oncol 2010, 28:1467-1472.

42. Takkouche B, Regueira-Mendez C, Etminan M: Breast cancer and use of nonsteroidal anti-inflammatory drugs: a meta-analysis. J Nat/ Cancer Inst 2008, 100:1439-1447.

43. Harker LA, Kadatz RA: Mechanism of action of dipyridamole. Thromb Res Supp/ 1983, 4:39-46.

44. Rothwell PM, Wilson M, Price JF, Belch JF, Meade TW, Mehta Z: Effect of daily aspirin on risk of cancer metastasis: a study of incident cancers during randomised controlled trials. Lancet 2012, 379:1591-1601.

45. van den Berg YW, Osanto S, Reitsma PH, Versteeg HH: The relationship between tissue factor and cancer progression: insights from bench and bedside. Blood 2012, 119:924-932.

46. Bluff JE, Brown NJ, Reed MW, Staton CA: Tissue factor, angiogenesis and tumour progression. Breast Cancer Res 2008, 10:204.

47. Ueno T, Toi M, Koike M, Nakamura S, Tominaga T: Tissue factor expression in breast cancer tissues: its correlation with prognosis and plasma concentration. Br J Cancer 2000, 83:164-170.

48. Hu C, Huang L, Gest C, Xi X, Janin A, Soria C, Li H, Lu H: Opposite regulation by PI3K/Akt and MAPK/ERK pathways of tissue factor expression, cellassociated procoagulant activity and invasiveness in MDA-MB-231 cells. J Hematol Oncol 2012, 5:16.

49. Ryden L, Grabau D, Schaffner F, Jonsson PE, RufW, Belting M: Evidence for tissue factor phosphorylation and its correlation with protease-activated receptor expression and the prognosis of primary breast cancer. Int J Cancer 2010, 126:2330-2340

50. Vrana JA, Stang MT, Grande JP, Getz MJ: Expression of tissue factor in tumor stroma correlates with progression to invasive human breast cancer: paracrine regulation by carcinoma cell-derived members of the transforming growth factor beta family. Cancer Res 1996, 56:5063-5070.

51. Albrektsen T, Sorensen BB, Hjorto GM, Fleckner J, Rao LV, Petersen LC: Transcriptional program induced by factor VIla-tissue factor, PAR1 and PAR2 in MDA-MB-231 cells. J Thromb Haemost 2007, 5:1588-1597.

52. Zwicker Jl, Liebman HA, Neuberg D, Lacroix R, Bauer KA, Furie BC, Furie B: Tumor-derived tissue factor-bearing microparticles are associated with venous thromboembolic events in malignancy. Clin Cancer Res 2009, 15:6830-6840

53. Tesselaar ME, Romijn FP, Van Der Linden IK, Prins FA, Bertina RM, Osanto S: Microparticle-associated tissue factor activity: a link between cancer and thrombosis? J Thromb Haemost 2007 5:520-527.

54. Versteeg HH, Schaffner F, Kerver M, Petersen HH, Ahamed J, FeldingHabermann B, Takada Y, Mueller BM, RufW: Inhibition of tissue factor signaling suppresses tumor growth. Blood 2008, 111:190-199.

55. Cole $\mathrm{M}$, Bromberg $\mathrm{M}$ : Tissue factor as a novel target for treatment of breast cancer. Oncologist 2013, 18:14-18.

56. Marchetti M, Russo L, Balducci D, Falanga A: All trans-retinoic acid modulates the procoagulant activity of human breast cancer cells. Thromb 
Res 2011, 128:368-374.

57. Falanga A, Toma S, Marchetti M, Palumbo R, Raffo P, Consonni R, Marziali S, Dastoli G, Barbui T: Effect of all-trans-retinoic acid on the hypercoagulable state of patients with breast cancer. Am J Hematol 2002, 70:9-15.

58. Shoji M, Sun A, Kisiel W, Lu YJ, Shim H, McCarey BE, Nichols C, Parker ET, Pohl J, Mosley CA, Alizadeh AR, Liotta DC, Snyder JP: Targeting tissue factorexpressing tumor angiogenesis and tumors with EF24 conjugated to factor VIla. J Drug Target 2008, 16:185-197.

59. Yu JL, Xing R, Milsom C, Rak J: Modulation of the oncogene-dependent tissue factor expression by kinase suppressor of ras 1. Thromb Res 2010, 126:e6-10.

60. Zhang X, Yu H, Lou JR, Zheng J, Zhu H, Popescu NI, Lupu F, Lind SE, Ding WQ: MicroRNA-19 (miR-19) regulates tissue factor expression in breast cancer cells. J Biol Chem 2011, 286:1429-1435.

61. Koizume S, Jin MS, Miyagi E, Hirahara F, Nakamura Y, Piao JH, Asai A, Yoshida A, Tsuchiya E, Ruf W, Miyagi Y: Activation of cancer cell migration and invasion by ectopic synthesis of coagulation factor VII. Cancer Res 2006, 66:9453-9460.

62. Contrino J, Hair G, Kreutzer DL, Rickles FR: In situ detection of tissue factor in vascular endothelial cells: correlation with the malignant phenotype of human breast disease. Nat Med 1996, 2:209-215.

63. Garnier D, Magnus N, D'Asti E, Hashemi M, Meehan B, Milsom C, Rak J: Genetic pathways linking hemostasis and cancer. Thromb Res 2012, 129 Suppl 1:S22-29.

64. Jiang X, Zhu S, Panetti TS, Bromberg ME: Formation of tissue factor-factor VIla-factor Xa complex induces activation of the mTOR pathway which regulates migration of human breast cancer cells. Thromb Haemost 2008, 100:127-133.

65. Hjortoe GM, Petersen LC, Albrektsen T, Sorensen BB, Norby PL, Mandal SK, Pendurthi UR, Rao LV: Tissue factor-factor VIla-specific up-regulation of IL-8 expression in MDA-MB-231 cells is mediated by PAR-2 and results in increased cell migration. Blood 2004, 103:3029-3037.

66. Coughlin SR: Thrombin signalling and protease-activated receptors. Nature 2000, 407:258-264

67. Even-Ram S, Uziely B, Cohen P, Grisaru-Granovsky S, Maoz M, Ginzburg Y, Reich R, Vlodavsky I, Bar-Shavit R: Thrombin receptor overexpression in malignant and physiological invasion processes. Nat Med 1998, 4:909-914.

68. Hu L, Lee M, Campbell W, Perez-Soler R, Karpatkin S: Role of endogenous thrombin in tumor implantation, seeding, and spontaneous metastasis. Blood 2004, 104:2746-2751.

69. DeFeo K, Hayes C, Chernick M, Ryn JV, Gilmour SK: Use of dabigatran etexilate to reduce breast cancer progression. Cancer Biol Ther 2010 10:1001-1008

70. Caunt M, Hu L, Tang T, Brooks PC, Ibrahim S, Karpatkin S: Growth-regulated oncogene is pivotal in thrombin-induced angiogenesis. Cancer Res 2006, 66:4125-4132.

71. Schaffner F, Versteeg HH, Schillert A, Yokota N, Petersen LC, Mueller BM, RufW: Cooperation of tissue factor cytoplasmic domain and PAR2 signaling in breast cancer development. Blood 2010, 116:6106-6113.

72. Nierodzik ML, Karpatkin S: Thrombin induces tumor growth, metastasis, and angiogenesis: Evidence for a thrombin-regulated dormant tumor phenotype. Cancer Cell 2006, 10:355-362.

73. Rak J, Milsom C, May L, Klement P, Yu J: Tissue factor in cancer and angiogenesis: the molecular link between genetic tumor progression, tumor neovascularization, and cancer coagulopathy. Semin Thromb Hemost 2006, 32:54-70

74. Han B, Nakamura M, Mori I, Nakamura Y, Kakudo K: Urokinase-type plasminogen activator system and breast cancer (Review). Oncol Rep 2005, 14:105-112.

75. Look MP, van Putten WL, Duffy MJ, Harbeck N, Christensen IJ, Thomssen C, Kates R, Spyratos F, Fernö M, Eppenberger-Castori S, Sweep CG, Ulm K, Peyrat
JP, Martin PM, Magdelenat H, Brünner N, Duggan C, Lisboa BW, Bendahl PO, Quillien V, Daver A, Ricolleau G, Meijer-van Gelder ME, Manders P, Fiets WE, Blankenstein MA, Broët P, Romain S, Daxenbichler G, Windbichler G, et al: Pooled analysis of prognostic impact of urokinase-type plasminogen activator and its inhibitor PAl-1 in 8377 breast cancer patients. J Natl Cancer Inst 2002, 94:116-128.

76. Wolff C, Malinowsky K, Berg D, Schragner K, Schuster T, Walch A, Bronger H, Hofler $\mathrm{H}$, Becker KF: Signalling networks associated with urokinase-type plasminogen activator (UPA) and its inhibitor PAl-1 in breast cancer tissues: new insights from protein microarray analysis. J Pathol 2011 223:54-63.

77. Malinowsky K, Wolff C, Berg D, Schuster T, Walch A, Bronger H, Mannsperger H, Schmidt C, Korf U, Höfler H, Becker KF: uPA and PAl-1-Related Signaling Pathways Differ between Primary Breast Cancers and Lymph Node Metastases. Trans/ Oncol 2012, 5:98-104.

78. Hurst NJ Jr., Najy AJ, Ustach CV, Movilla L, Kim HR: Platelet-derived growth factor-C (PDGF-C) activation by serine proteases: implications for breast cancer progression. Biochem J 2012, 441:909-918.

79. Bajou K, Lewalle JM, Martinez CR, Soria C, Lu H, Noel A, Foidart JM: Human breast adenocarcinoma cell lines promote angiogenesis by providing cells with UPA-PAI-1 and by enhancing their expression. Int J Cancer 2002 100:501-506

80. Kakkar AK, Levine MN, Kadziola Z, Lemoine NR, Low V, Patel HK, Rustin G, Thomas M, Quigley M, Williamson RC: Low molecular weight heparin therapy with dalteparin, and survival in advanced cancer: the fragmin advanced malignancy outcome study (FAMOUS). J Clin Oncol 2004, 22:1944-1948.

81. Sideras K, Schaefer PL, Okuno SH, Sloan JA, Kutteh L, Fitch TR, Dakhil SR, Levitt R, Alberts SR, Morton RF, Rowland KM, Novotny PJ, Loprinzi CL: Lowmolecular-weight heparin in patients with advanced cancer: a phase 3 clinical trial. Mayo Clin Proc 2006, 81:758-767.

82. Klerk CP, Smorenburg SM, Otten HM, Lensing AW, Prins MH, Piovella F, Prandoni P, Bos MM, Richel DJ, van Tienhoven G, Büller HR: The effect of low molecular weight heparin on survival in patients with advanced malignancy. J Clin Oncol 2005, 23:2130-2135.

83. Agnelli G, Gussoni G, Bianchini C, Verso M, Mandalà M, Cavanna L, Barni S, Labianca R, Buzzi F, Scambia G, Passalacqua R, Ricci S, Gasparini G, Lorusso V, Bonizzoni E, Tonato M; PROTECHT Investigators: Nadroparin for the prevention of thromboembolic events in ambulatory patients with metastatic or locally advanced solid cancer receiving chemotherapy: a randomised, placebo-controlled, double-blind study. Lancet Oncol 2009, 10:943-949.

84. Levine M, Hirsh J, Gent M, Arnold A, Warr D, Falanga A, Samosh M, Bramwell V, Pritchard Kl, Stewart D, et al.: Double-blind randomised trial of a very-lowdose warfarin for prevention of thromboembolism in stage IV breast cancer. Lancet 1994, 343:886-889.

85. Golubkov VS, Strongin AY: Proteolysis-driven oncogenesis. Cell Cycle 2007 6:147-150.

86. Jiang X, Guo YL, Bromberg ME: Formation of tissue factor-factor Vlla-factor Xa complex prevents apoptosis in human breast cancer cells. Thromb Haemost 2006, 96:196-201.

87. Powles TJ, Dady PJ, Williams J, Easty GC, Coombes RC: Use of inhibitors of prostaglandin synthesis in patients with breast cancer. Adv Prostaglandin Thromboxane Res 1980, 6:511-516.

doi:10.1186/bcr3425

Cite this article as: Lal I, et al:: Platelets, coagulation and fibrinolysis in breast cancer progression. Breast Cancer Research 2013, 15:207. 